UDC 576.32, 577.2

\title{
Alterations in expression of S6K1 isoforms in MCF7 cells have a strong impact on the locomotor activity as well as on S6K1 and Akt signaling
}

\author{
V. R. Kosach, N. Ya. Hotsuliak, I. V. Zaiets, O. M. Skorokhod, L. O. Savinska, \\ A. I. Khoruzhenko, V. V. Filonenko \\ Institute of Molecular Biology and Genetics, NAS of Ukraine \\ 150, Akademika Zabolotnoho Str., Kyiv, Ukraine, 03143 \\ filonenko@imbg.org.ua
}

\begin{abstract}
Aim. To generate and characterize MCF-7 cell lines with altered expression of p85, p70 and p60 S6K1 isoforms: p85-/p70-/p60-MCF-7 and p85-/p70-/p60+MCF-7. Methods. CRISPR/ Cas9 gene editing, western blot analysis, immunofluorescence analysis, scratch assay. Results. Modified MCF-7 cells with knocked down expression of p85, p70, p60 or only p85 and p70 S6K1 isoforms were generated. Selective inhibition of only p85 and p70 isoforms in p85-/p70-/p60+MCF-7 cells was accompanied by actin cytoskeleton rearrangements, appearance of fibroblast-like cell morphology and significantly increased cell locomotor activity. Downregulation of all three S6K1 isoforms in p85-/p70-/p60 - MCF-7 cells inhibited cell migration with no changes in the cell morphology. Alterations in had a different impact on the ribosomal protein S6 phosphorylation and Akt signaling. Conclusion. Analysis of the modified MCF-7 cell lines revealed different impact of expression of S6K1 isoforms on MCF7 cell locomotor activity and the S6K1- and Akt-dependent signaling. Our data suggest that p60S6K1 could be involved in regulation of the cell migration. The generated cells can be used for further analysis of functional activity of the S6K1 isoforms.
\end{abstract}

Ke y w o r d s: mTOR/S6K1 signaling, MCF-7, S6K1, CRISPR/Cas9, breast cancer

\section{Introduction}

According to the National Cancer Registry, malignant tumors of the mammary gland make up the largest proportion in the structure of the cancer incidence of female population [1]. One of the main causes of death of patients with this type of cancer is the ability of cells to form distant metastases [2]. Therefore, the study of molecular mechanisms involved in the regulation of the motility of breast cancer cells is necessary to understand the processes of metastasis formation and to improve anticancer therapy.

An important signaling cascade that provides intracellular signaling in the epithelium

C 2020 V. R. Kosach et al.; Published by the Institute of Molecular Biology and Genetics, NAS of Ukraine on behalf of Biopolymers and Cell. This is an Open Access article distributed under the terms of the Creative Commons Attribution License (http://creativecommons.org/licenses/by/4.0/), which permits unrestricted reuse, distribution, and reproduction in any medium, provided the original work is properly cited 
of the mammary gland is the $\mathrm{PI} 3 \mathrm{~K} / \mathrm{mTOR} / \mathrm{S} 6 \mathrm{~K}$ pathway [3]. This cascade plays a key role in signaling from insulin, thyroid stimulating hormone, estrogen and a number of growth factors, providing control of many physiological functions in cells, in particular: growth, metabolism, proliferation, and motility [4].

The ribosomal protein S6 kinase ( $\mathrm{S} 6 \mathrm{~K} 1)$ is one of the key players of this signaling and represents an extensively studied effector of the mTOR. To date, numerous studies indicate an important role of S6K1 in cancer progression. Overexpression of the $S 6 K 1$ gene and deregulation of S6K1 signaling have been found in different malignancies, including breast, prostate, thyroid, brain and gastric cancers [5-12] that according to multiple studies correlates with poor prognosis of disease $[6$, 11-13]. Additionally, there is some data indicating that resistance of estrogen positive tumors to anti-estrogen therapy is tightly linked to S6K1 signaling [14. 15]. S6K1 has been involved in regulation of cell proliferation [16] and motility $[17,18]$ that are affected in transformed cells as well. Therefore, the study of the $\mathrm{S} 6 \mathrm{~K} 1$ role in the cancer cells proliferation and migration is an urgent task for researchers.

The S6K1 gene (RPS6KB1), located in the chromosomal regions $17 \mathrm{q} 21-23$, is commonly amplified in breast cancer $[27,28]$ and encodes several S6K1 isoforms that are formed as a result of an alternative mRNA translation and/ or splicing events. In human cells several S6K1 isoforms are known: p85-S6K1, p70S6K1, p60-S6K1 and p31-S6K1 [19-21]. To date, there is very limited information about the functional role and regulation of different $\mathrm{S} 6 \mathrm{~K} 1$ isoforms. Therefore, there is a need for the creation of cellular models with altered expression of different $\mathrm{S} 6 \mathrm{~K} 1$ isoforms in cell lines of different origin, which will allow studying their functions and regulation as well as implication in the cancer development and progression.

The aim of this work was to create and characterize the MCF-7 cell lines with disrupted expression of different $\mathrm{S} 6 \mathrm{~K} 1$ isoforms. We selected the breast adenocarcinoma MCF-7 cell line because it is characterized by the S6K1 gene amplification and increased S6K1 protein expression, but has never been analyzed for functional activity and regulation of different S6K1 isoforms.

Recently, applying the CRISPR Cas9 gene editing technology we generated HEK293 cells with differential expression of the S6K1 isoforms [22, 23]. Analysis of the modified HEK293 cell lines revieled that p70, p85 and p60 S6K1 isoforms have different modes of regulation and as a consequence have different impact on cell behavior. According to our data [24] the p85-/p70-/p60 - HEK-293 cells exhibited down-regulation of Akt phosphorylation on Ser473 and possibly activity, and subsequent attenuation of cell growth rate, as well as inhibition of cell motility. Disruption of only two isoforms (p85 and p70) had an inhibitory effect on the cell proliferation and motility as well, however, the extent of inhibition was not so profound in case of sustained p60-S6K1 expression. It seems that $\mathrm{p} 60-\mathrm{S} 6 \mathrm{~K} 1$ to some extent could rescue the cells from inhibitory effect caused by the inhibition of $\mathrm{p} 85$ - and p70-S6K1 expression. Additionally, our data demonstrated that the regulation of p60 isoform in HEK293 and MCF-7 cell lines was different. In contrast to MCF-7, in HEK 293 cells the p60 S6K1 isoform was not phos- 
phorylated at critical for the p70S6K1 activity T389 site and so not regulated by mTOR. Based on the data received we assumed that in MCF-7 cells that in contrast to HEK293 are of tumor origin, S6K1 isoforms and particularly the p60 isoform may have the functions and impact on cell proliferation and motility different than in HEK293.

To create the MCF-7 cell lines with downregulated expression of all $\mathrm{S} 6 \mathrm{~K} 1$ isoforms or only main - p85 and p70 with unaffected expression of p60 isoform we introduced the CRISPR Cas9 gene editing technology and used the same DNA constructs as for HEK 293 cells $[22,23]$.

The expression level of S6K1 isoforms was studied with western blot and immunofluorescence analyses. Morphology and migratory potential of obtained cell lines were analysed.

\section{Materials and Methods}

gRNA design and cloning. gRNA oligonucleotides complementary to the sequence of the target gene were designed using the web tool http://crispr.mit.edu/. The sequences of gRNA oligonucleotides and gRNAs cloning into pSpCas9(BB)-2A-Puro (PX459) V2.0 vector were described in $[22,23]$.

Cell culture and generation of MCF-7 cells with the edited S6K1 gene. Human breast adenocarcinoma cell line MCF-7 was obtained from Bank of Cell Lines of the R. E. Kavetsky Institute of Experimental Pathology, Oncology and Radiobiology, NASU (Ukraine). The cells were cultivated in DMEM culture medium (Gibco, USA) supplemented with $10 \%$ fetal calf serum (FCS, HyClone, USA), $4 \mathrm{mM}$ glutamine, 50 units $/ \mathrm{ml}$ penicillin, $50 \mu \mathrm{g} / \mathrm{ml}$ streptomycin at $37^{\circ} \mathrm{C}$ under $5 \% \mathrm{CO} 2$. Transfection of MCF-7 cells by pSpCas9(BB)-2A-Puro (PX459) V2.0 with specific gRNAs [22, 23] was carried out using jetPEI transfection reagent (Polyplus-transfection, USA). The procedure was performed following manufacturer's instructions. The cells were seeded onto a 24-well plate before transfection and grown for 24 hours following transfection with $1 \mu \mathrm{g}$ of the DNA constructs encoding the gRNAs targeting corresponding regions of the S6K1 gene $[22,23]$.

The cells were seeded onto $10-\mathrm{cm}$ cell culture dishes 24 hours posttransfection and selected with puromycin $(4 \mu \mathrm{g} / \mathrm{mL})$ for 48 hours. After selection the separate clones were picked up for further analysis.

Western blot analysis. MCF-7 cells were washed with ice-cold phosphate-buffered saline and extracted with lysis buffer, containing $20 \mathrm{mM}$ Tris- $\mathrm{HCl}$ (pH 7.5), $150 \mathrm{mM} \mathrm{NaCl}, 1 \%$ Triton $\mathrm{X}-100,5 \mathrm{mM}$ EDTA, $50 \mathrm{mM}$ sodium fluoride, $5 \mathrm{mM} \beta$-glycerophosphate, $10 \mathrm{mM}$ sodium pyrophosphate, $1 \mathrm{mM}$ sodium orthovanadate and a mixture of protease inhibitors (Roche Molecular Diagnostics, France). Cell lysates were centrifuged at $13000 \mathrm{rpm}$ for $20 \mathrm{~min}$ at $4^{\circ} \mathrm{C}$ and the supernatant was collected. The protein concentrations were determined using Bradford assay. Equal amounts of protein were resolved in $10 \%$ SDS-PAGE and electrotransferred onto polyvinylidene difluoride (PVDF) membranes for immunoblotting. The membrane was blocked with $5 \%$ low-fat milk in TBS-T (50 mM Tris$\mathrm{HCl}, \mathrm{pH} 7.4,150 \mathrm{mM} \mathrm{NaCl}$ and $0.1 \%$ Tween-20) and incubated with antibodies overnight at $4{ }^{\circ} \mathrm{C}$. The antibodies were diluted in TBS-T for use as follows: anti-S6K1-C-terminus (generated as described in [25]) 1:3000, 
anti- $\beta$-actin (clone 13E5, Sigma) 1:20000, anti-phospho-S6 ribosomal protein (Ser240/244) (\#5364, Cell Signaling Technologies) 1:2000, anti-phospho-Akt (Ser473) (\#9271, Cell Signaling Technologies) 1:2000, anti-phospho-Akt-substrates (\#9614, Cell Signaling Technologies) 1:2000. After washing three times with TBS-T, HRP conjugated secondary antibodies (Jackson ImmunoResearch Labs) in 1:10000 dilution in TBS-T were incubated with the membranes for 1 hour at room temperature. The signal was developed using an enhanced chemiluminescence system (Fluco) and then exposed to Agfa $\mathrm{X}$-ray film.

Immunofluorescence analysis of $M C F-7$ cell lines. MCF-7 cells were seeded onto cover glasses and cultured for 48 hours. Cultured MCF-7 cells were fixed with $10 \%$ formalin for $15 \mathrm{~min}$ at room temperature (RT). Thereafter, the cells were permeabilized with $0.2 \%$ Triton X-100 in PBS for $10 \mathrm{~min}$. Autofluorescence was decreased by incubation with $10 \mathrm{mM}$ cupric sulphate and $50 \mathrm{mM}$ ammonium acetate, $\mathrm{pH} 5.0$ for $30 \mathrm{~min}$ at RT. Nonspecific binding was blocked after incubation with $10 \% \mathrm{FCS}$ in PBS for $30 \mathrm{~min}$ at $37^{\circ} \mathrm{C}$ in a humidifying chamber. For S6K1 detection the samples were incubated with rabbit polyclonal anti-C-terminal S6K1 antibodies [25] in dilution 1:100 in blocking buffer overnight at $+4{ }^{\circ} \mathrm{C}$. The secondary (FITC)-AffiniPure Goat Anti-Rabbit IgG antibodies (Jackson ImmunoResearch Labs Cat\# 111-095-003) were applied $1: 400$ for $45 \mathrm{~min}$ at $37^{\circ} \mathrm{C}$ in a humidified chamber. Samples were embedded into Mowiol medium (Sigma-Aldrich, USA) containing $2.5 \%$ DABCO (Sigma-Aldrich), $0.5 \%$ DAPI (Sigma-Aldrich). Microscopy image acquisition was performed using Zeiss LSM 510 META laser scanning confocal microscope (Carl Zeiss Microscopy $\mathrm{GmbH}$, Germany). Fluorescence images were analyzed using Fiji/ImageJ v1.52b.

In vitro scratch assay. In the present study, the wtMCF-7, p85-/p70-/p60+ MCF-7 and p85p70-/p60 - MCF-7 cells were plated $\left(5 \times 10^{5}\right)$ in 6-well plates and grown to $90 \%$ confluence. The confluent monolayer was scraped with $200 \mu 1$ sterile pipette tips to leave a scratch. After the scratch was created, digitized images of a wound closure were taken at $0 \mathrm{~h}$ and $24 \mathrm{~h}$ with the Leica DM 1000 microscope and a digital camera. The average distance $(\mu \mathrm{m})$ between the wound edges was determined at each time point as it was described in [26]. The scratch wound assay was performed in triplicates for each cell line used in this study.

Statistical analysis. All results are expressed as the means \pm standard deviation (S.D.) from three independent experiments. Statistical significance of differences between two groups was determined by using Student's $t$-test. The difference between groups was considered to be statistically significant at $p<0.01$ and $p<0.005$.

\section{Results and Discussion}

Generation of MCF-7 cell lines with altered S6K1 isoforms expression

The main aim of this work was to obtain human breast adenocarcinoma MCF-7 cell lines with inhibited expression of all kinase isoforms (p85//p70-/p60- MCF-7) and with expression of only p60-S6K1 (p85-/p70-/ $\left.\mathrm{p} 60^{+} \mathrm{MCF}-7\right)$. The CRISPR/Cas9 genome editing system was used for this purpose. MCF-7 
cells were transfected with pSpCas9(BB)-2APuro (PX459) V2.0 encoding anti-p85/p70/ p60-S6K1 gRNA or anti-p85/p70-S6K1 gRNA created previously $[22,23]$. Briefly, for the expression inhibition of all three alternatively translated S6K1 isoforms, gRNA targeted sequence was located downstream of S6K1 isoforms translation starts and right after the third, p60 isoform translation start. However for down regulation of only $\mathrm{p} 70$ - and p85-S6K1 expression the location of targeting region was upstream of the p60-S6K1 translation start, but downstream of that for $\mathrm{p} 85$ - and p70-S6K1 isoforms. Upon selection, 5 clones of $\mathrm{p} 85 \%$ p70-/p60- MCF-7 and 5 clones of p85 /p70-/ p60 ${ }^{+}$MCF-7 were picked up and checked for S6K1 expression by western blot analysis. Wild type MCF-7 cells were used as control.

It was found that expression of all S6K1 isoforms was significantly down regulated in all p85-/p70-/p60-MCF-7-clones compared to control MCF7 cells (Fig. 1.A). In all clones analysed we observed complete inhibition of p85-S6K1. Expression of p60-S6K1 varied among clones from complete inhibition (clones $\# 2,4,5)$ to significant decrease (clones \#1, 3) compared to the wild-type cells. Expression of the most abundant p70 isoform of S6K1 was characterized by a significant decrease in most clones (\#1-4), whereas its complete absence was shown only in one clone (\#5). Thus, the most effective knockdown of S6K1 isoforms expression was achieved in clone 5 and this clone was chosen for further analysis.

Western blot analysis of lysates of the $\mathrm{p} 85 \%$ p70-/p60 ${ }^{+} \mathrm{MCF}-7$ cells revealed the expression of p60-S6K1 in all clones obtained (Fig. 1.B). The most effective knock down of p70/p85 isoforms expression with unaffected expression of p60 was detected only in clone \#2 that was selected for further analysis.

It is known that RPS6KB1 gene is often amplified in breast tumors and in numerous breast tumor cell lines including MCF-7.

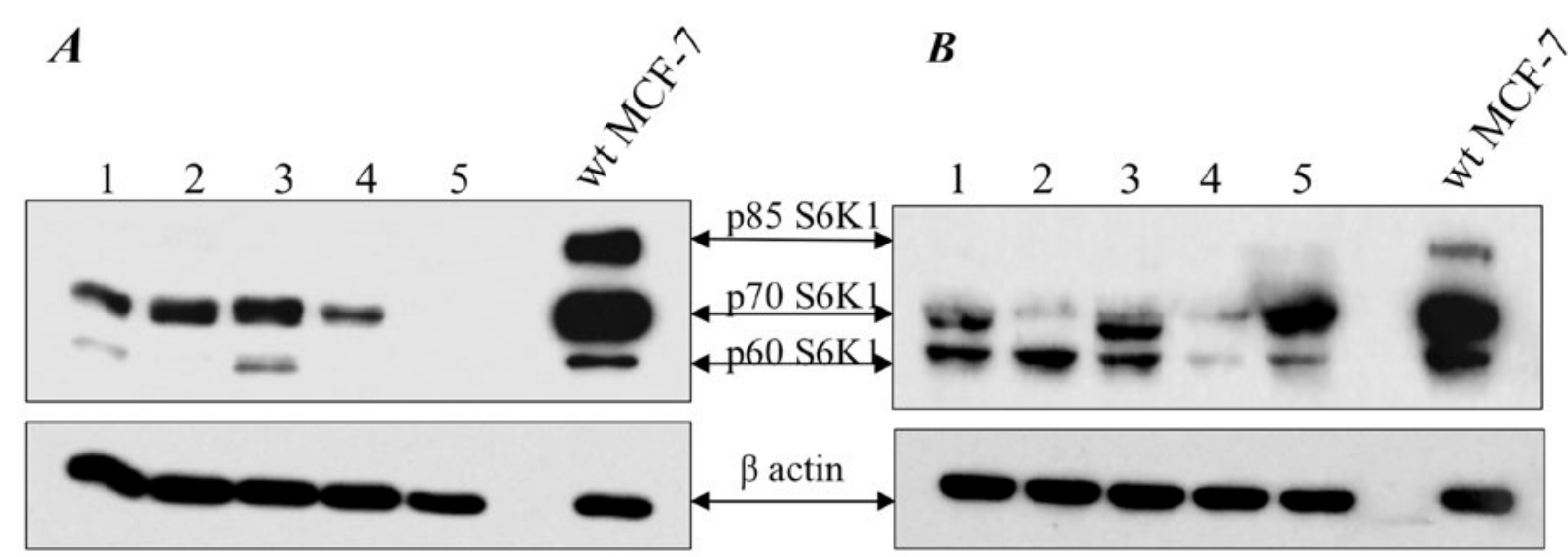

Fig.1. Western blot analysis of S6K1 isoform expression in MCF-7 cell lines obtained after editing the RPS6K1 gene by CRISPR/Cas9 system. Detection of S6K1 protein in lysates was performed using antibodies against the C-terminal region of S6K1. $\beta$ actin was used as a control of the deposition of samples. $A$ - Western blot analysis of p85\%/p $70 \%$ p60 - MCF-7cells: $1-5$ - obtained clones, wtMCF-7 - wild-type MCF-7 cells. $B$ - Western blot analysis of p85-/p70-/ p60 ${ }^{+}$MCF-7 cells: $1-5$ - obtained clones, wtMCF-7 - wild-type MCF-7 cells. 
Additionally, slight heterogeneity in the number of chromosomes can be observed within a population of the MCF-7 cell line itself [27]. Therefore, it may explain different efficiency of the CRISPR/Cas9 induced gene editing and generation of clones with different extent of S6K1 isoforms expression inhibition.

The following immunofluorescence analysis of selected clones with the anti-S6K1 antibod- ies specific to the C-terminal region of the kinase presented in all studied isoforms has confirmed a complete loss of S6K1 expression in $\mathrm{p} 85 \% / \mathrm{p} 70-/ \mathrm{p} 60-\mathrm{MCF}-7$. At the same time, $\mathrm{p} 85^{-} / \mathrm{p} 70^{-} / \mathrm{p} 60^{+} \mathrm{MCF}-7$ cells were characterized by a weak, mostly nuclear, positive response presumably specific for p60 S6K1 (Fig. 2), which correlated with previous western blot analysis.

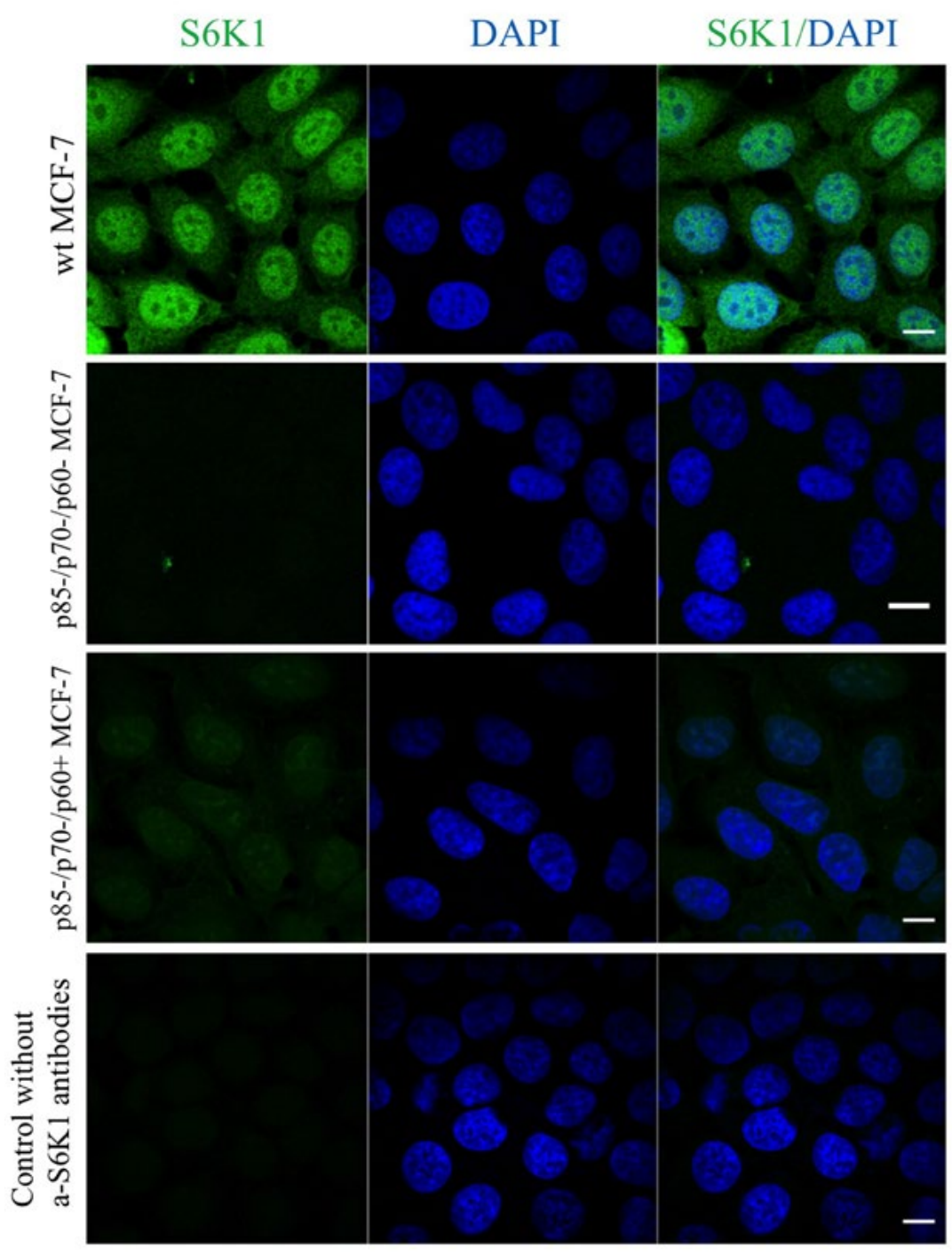

Fig.2. Immunofluorescence analysis of the S6K1 in MCF-7 cells after editing of the RPS6K1 gene by CRIS$\mathrm{PR} / \mathrm{Cas} 9$ system. Detection of S6K1 protein was performed using antibodies against the $\mathrm{C}$-terminal region of S6K1 molecule (green). Nuclei were stained with DAPI (blue). Scale $10 \mu \mathrm{m}$. 
In general, the morphological analysis of obtained cell lines demonstrated that $\mathrm{p} 85 \% / \mathrm{p} 70-/$ p60 - MCF-7 cells morphologically did not differ significantly from wild-type cells. They had a distinctive epithelial shape and formed separate islets of cells due to intercellular contacts (Fig. 3). However, the cells of p85-/p70 $/$ p60 $0^{+}$MCF-7 line with inhibited $\mathrm{p} 70$ and $\mathrm{p} 85$ S6K1 isoforms and preserved p60-S6K1 expression were characterized by the appearance of elongated cells with signs of the cytoskeletal remodeling known as hallmarks of migrating cells (Fig. 3). It is known that S6K1 is involved in the regulation of the architecture of the actin filaments [28] as well as in [the] regulation of cell motility $[29,30]$. However, the role of $\mathrm{p} 60-\mathrm{S} 6 \mathrm{~K} 1$ in this process remains unexplored.

To estimate the participation of S6K1 isoforms in cell migration processes we applied scratch assay (Fig. 4). It was revealed that knock down of all three isoforms expression (p85/p70-/p60 - MCF-7 cells) caused a de- crease in the migration activity of MCF7 cells similar to that observed in HEK293 cells [22]. In contrast, the motility rate of $\mathrm{p} 85^{-} / \mathrm{p} 70^{-} /$ p $60^{+} \mathrm{MCF}-7$ cells with preserved expression of p60-S6K1 isoform increased more than twice compared to the wild type cells. In general, the disturbances in S6K1 isoforms expression in MCF-7 cells had more profound effect on cells migration than in HEK293.

The increased locomotor activity of cells with preserved expression of $\mathrm{p} 60-\mathrm{S} 6 \mathrm{~K} 1$ isoform raised the question of its impact on the mTOR/S6K1 signaling in the created MCF-7 cell lines. Earlier we demonstrated that in HEK 293 cells the down regulation of S6K1 isoforms expression has no effect on the phosphorylation (Ser240/244) of ribosomal protein S6 (rpS6) that is the one of the main S6K1 substrates. That could be explained by the presence in cells of highly homologous S6K2 form that shares most substrates with S6K1 including $\mathrm{rpS} 6$ and that could be responsible for rpS6 phosphorylation in HEK293 cells.

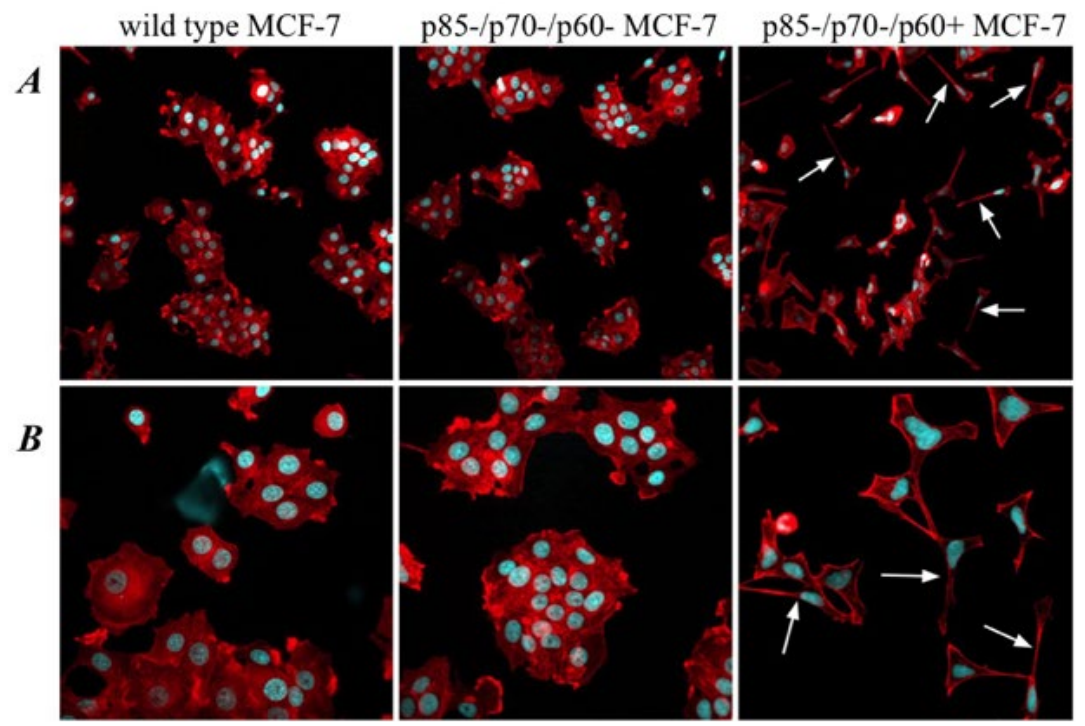

Fig.3. Fluorescence microscopy of MCF-7 cell lines obtained after editing the RPS6K1 gene by CRISPR/ Cas9 system. Actin cytoskeleton was stained with phalloidin-TRITC (red). Nuclei were stained with DAPI (Blue). White arrows point to the cells with elongated shape. $A-20 \mathrm{x}$ objective. $B-40 \mathrm{x}$ objective. 
A

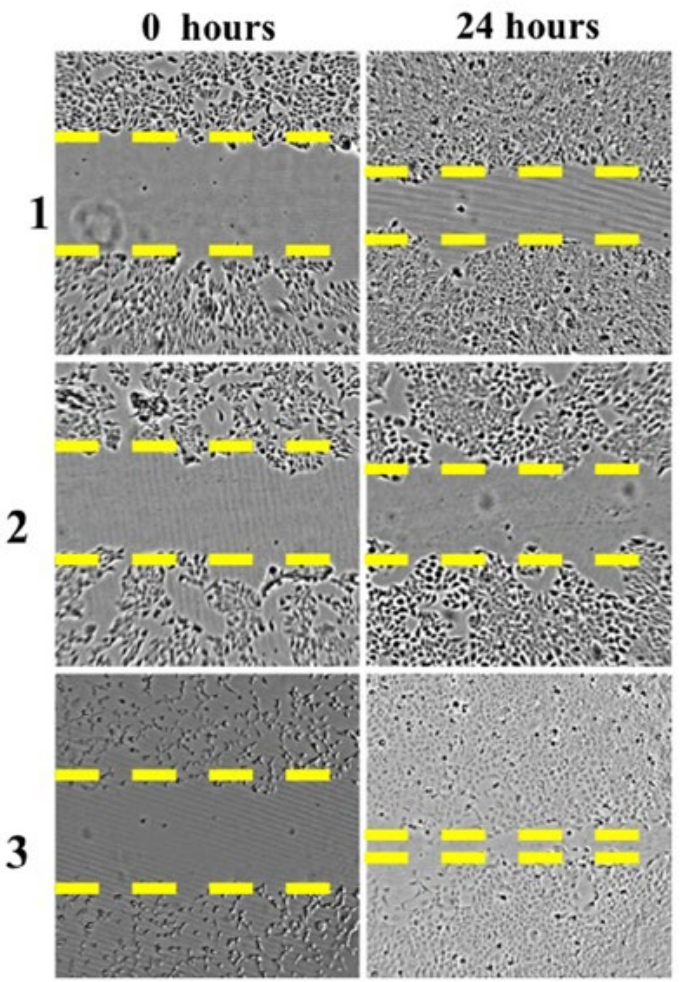

However in MCF-7 cells with inhibited S6K1 isoforms expression, phosphorylation of $\mathrm{rpS} 6$ was significantly lower at all conditions of cell growth analysed compared to parental MCF-7 cells (Fig. 5). Additionally, rpS6 phosphorylation profile differed even between $\mathrm{p} 85^{-/} \mathrm{p} 70^{-} /$ p60 - and p85-/p70-/p60 MCF-7 cells under certain conditions of cell growth. According to our data phosphorylation of rpS6 was completely inhibited in both modified MCF-7 cell clones after $24 \mathrm{~h}$ starvation in serum free medium (Fig. 5), however within $1 \mathrm{~h}$ after cell restimulation by serum, phosphorylation of rpS6 was restored only in $\mathrm{p} 85-\mathrm{p} 70^{-} /$ p60 ${ }^{+}$MCF-7, but not in p85-/p70-/p60- MCF-7 cells. Taken together, the above data suggest not only different functions of S6K1 in

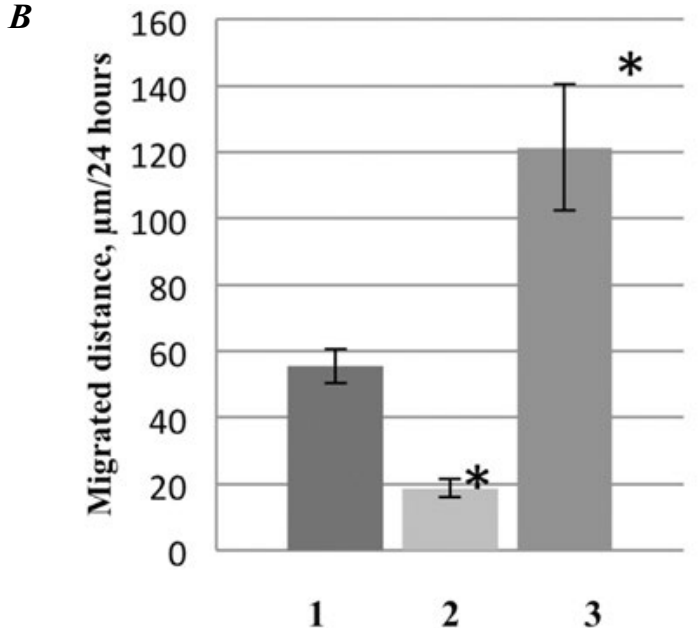

Fig.4. Analysis of migration of the generated MCF-7 cell lines by in vitro scratch assay. $A$ - light microscopy of the artificial wound at $0 \mathrm{~h}$ and $24 \mathrm{~h}$ after scratch. 1 - wild type MCF-7, 2 - p85-/p70-/p60 - MCF-7cells, 3 - p85-/p70/ p $60^{+}$MCF-7 cells. Yellow lines show the edges of the scratch. $B$ - Histogram shows the migrated distance in micrometers for 24 hours. 1 - wild type MCF-7, 2 - p85-/ p70-/p60 - MCF-7cells, 3 - p85-/p70-/p60 ${ }^{+}$MCF-7 cells. * $-\mathrm{p} \leq 0,01$ versus wtMCF-7.

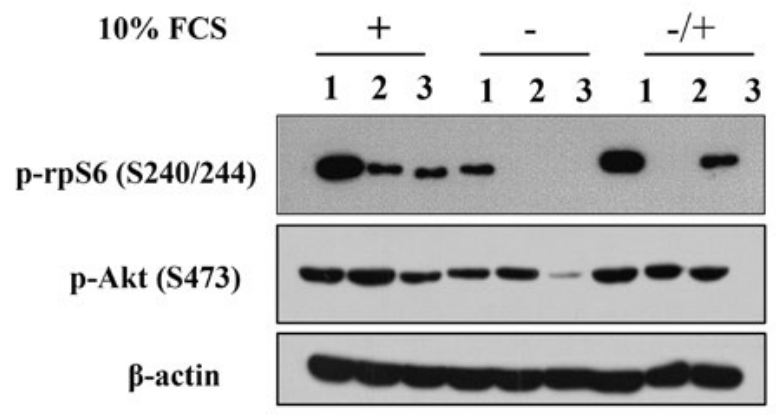

Fig.5. Western blot analysis of Akt/mTOR/S6K1 signaling in MCF-7 cells after editing of the RPS6K1 gene by CRISPR / Cas9 system. After 24 hours of serum starvation, MCF-7 cell lines were treated with $10 \%$ fetal calf serum (FCS) for 1 hour. Protein lysates were prepared from the cells and analyzed for the Akt/mTOR/S6K1 signalling pathway by Western blotting. Antibody against $\beta$-actin was used to ensure each protein sample was loaded equally. 1 - wild type MCF-7, 2 - p85-/p70-/p60 MCF-7cells, 3 - p85-/p70-/p60+ MCF-7cells. 
HEK293 and MCF-7 cells, but different functions of S6K1 isoforms in MCF-7 cells.

Another key component of mTOR signaling Akt kinase is also involved in the cytoskeleton rearrangement and the regulation of cell migration [31]. Its phosphorylation/activity could be modulated by S6K1 via mTORC2 complex [31]. Western blot analysis did not revealed any significant difference in the level of Akt phosphorylation between wild-type MCF-7 and p85-/p70-/p60 - MCF-7 cells. However, p85-/p70 $/ \mathrm{p} 60^{+} \mathrm{MCF}-7$ cells under standard growth conditions had a slightly reduced p-Akt S473 content, but after starvation, a reduction was already significant versus wild-type and even p85/p70-/p60 - MCF-7 cells (Fig. 5).

As the level of Akt phosphorylation was different in $\mathrm{p} 85^{-} / \mathrm{p} 70^{-} / \mathrm{p} 60^{+} \mathrm{MCF}-7$ cells that had elevated locomotor activity, our next step was to estimate the activity of Akt by analyzing phosphorylation profile of Akt kinase substrates in the cell lines obtained (Fig. 6).

Western blot analysis revealed that disturbances in S6K1 isoforms expression have a significant effect on the phosphorylation of a number of Akt substrates. At the same time phosphorylation of some Akt substrates was dramatically different in $\mathrm{p} 85^{-} / \mathrm{p} 70^{-} / \mathrm{p} 60-$ MCF-7 and $\mathrm{p} 85^{-} / \mathrm{p} 70^{-} / \mathrm{p} 60^{+} \mathrm{MCF}-7$ cells suggesting the involvement of these proteins in cell migration. This assumption definitely requires further studies using specific antibodies against Akt targets to determine the exact nature of the substrates involved in the regulation of these functions.

In conclusion, by CRISPR/Cas9 gene editing we generated modified MCF-7 cell lines with a complete loss of p60, p70 and p85 S6K1

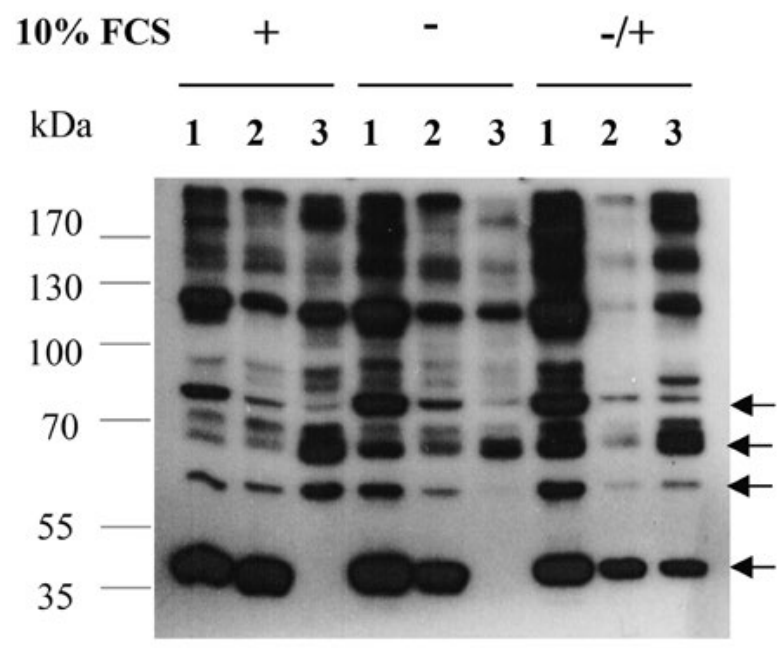

Fig.6. Western blot analysis of Akt substrates phosphorylation in MCF-7 cells after editing of the RPS6K1 gene by CRISPR / Cas 9 system. After 24 hours of the serum starvation, MCF-7 cell lines were treated with $10 \%$ fetal calf serum (FCS) for 1 hour. Protein lysates were prepared from the cells and analyzed for the phosphorylation of Akt substrates. 1 - wild type MCF-7, 2 - p85- / p70- /p60 - MCF-7cells, 3 - p85- /p70- /p60+ MCF7 cells.

isoforms expression (p85-/p70-/p60 - MCF-7), and with preserved expression of only $\mathrm{p} 60$ S6K1 (p85-/p70-/p60+ MCF-7). Analysis of the modified MCF-7 cell lines revealed different impact of the S6K1 isoforms expression on [the] MCF-7 cell locomotor activity and on the S6K1 - and Akt-dependent signaling. According to the presented data among S6K1 isoforms, p60-S6K1 could be the main player in the regulation of cell migration. The generated cells can be used for further analysis of functional activity of S6K1 isoforms.

\section{Funding}

This work was supported in part by the grant from NAS of Ukraine for young scientists (81$10 / 12-20)$. 


\section{REFERENCES}

1. Fedorenko Z, Michailovich Y, Goulak L, Gorokh Y, Ryzhov A, Soumkina O, Koutsenko L. Cancer in Ukraine, 2018-2019. Incidence, mortality, activities of oncological service. Bulletin of National Cancer Registry of Ukraine. 2020;21:1-10.

2. Takahashi H, Isogawa M. Management of breast cancer brain metastases. Chinese Clinical Oncology. 2018;7(3):30.

3. Fruman D, Chiu H, Hopkins B, Bagrodia S, Cantley L, Abraham R. The PI3K pathway in human disease. Cell. 2017;170(4):605-635.

4. Filonenko $V$. PI3K/mTOR/S6K signaling pathwaynew players and new functional links. Biopolym Cell. 2013;29(3):207-214.

5. Castellvi J, Garcia A, Rojo F, Ruiz-Marcellan C, Gil A, Baselga J, Ramon y Cajal S. Phosphorylated $4 \mathrm{E}$ binding protein 1: a hallmark of cell signaling that correlates with survival in ovarian cancer. Cancer. 2006; 107(8):1801-11.

6. Filonenko VV, Tytarenko R, Azatjan SK, Savinska LO, Gaydar YA, Gout IT, Usenko VS, Lyzogubov $V V$. Immunohistochemical analysis of $\mathrm{S} 6 \mathrm{~K} 1$ and S6K2 localization in human breast tumors. Exp Oncol. 2004; 26(4):294-9.

7. Lyzogubov V, Khozhaenko Y, Usenko V, Antonjuk S, Ovcharenko G, Tikhonkova I, Filonenko V. Immunohistochemical analysis of Ki-67, PCNA and S6K1/2 expression in human breast cancer. Exp Oncol. 2005; 27(2):141-4.

8. Barlund M, Forozan F, Kononen J, Bubendorf L, Chen Y, Bittner ML, Torhorst J, Haas P, Bucher C, Sauter G, Kallioniemi OP, Kallioniemi A. Detecting activation of ribosomal protein S6 kinase by complementary DNA and tissue microarray analysis. J Natl Cancer Inst. 2000: 92(15):12521259.

9. van der Hage JA, van den Broek LJ, Legrand C, Clahsen PC, Bosch CJ, Robanus-Maandag EC, van de Velde CJ, van de Vijver MJ. Overexpression of P70 S6 kinase protein is associated with increased risk of locoregional recurrence in node-negative premenopausal early breast cancer patients. $\mathrm{Br} J$ Cancer. 2004; 90(8):1543-50.
10. Bostner J, Karlsson E, Pandiyan MJ, Westman H, Skoog L, Fornander T, Nordenskjöld B, Stål O. Activation of Akt, mTOR, and the estrogen receptor as a signature to predict tamoxifen treatment benefit. Breast Cancer Res Treat. 2013; 137(2):397-406.

11. Bostner J, Karlsson E, Eding CB, Perez-Tenorio G, Franzén H, Konstantinell A, Fornander T, Nordenskjöld B, Stål $O$. S6 kinase signaling: tamoxifen response and prognostic indication in two breast cancer cohorts. Endocr Relat Cancer. 2015; 22(3):331-43.

12. Barlund M, Monni O, Kononen J, Cornelison R, Torhorst J, Sauter G, Kallioniemi O, Kallioniemi A. Multiple genes at 17q23 undergo amplification and overexpression in breast cancer. Cancer Res. 2000; 60(19):5340-4.

13. Ismail HM. Overexpression of S6 kinase 1 in brain tumours is associated with induction of hypoxiaresponsive genes and predicts patients' survival. J Oncol. 2012; 2012:416927.

14. Bostner J, Karlsson E, Pandiyan MJ, Westman H, Skoog L, Fornander T, Nordenskjöld B, Stål O. Activation of Akt, mTOR, and the estrogen receptor as a signature to predict tamoxifen treatment benefit. Breast Cancer Res Treat. 2013;137(2): 397-406.

15. Bostner J, Karlsson E, Eding CB, Perez-Tenorio G, Franzén H, Konstantinell A, Fornander T, Nordenskjöld B, Stål $O$. S6 kinase signaling: tamoxifen response and prognostic indication in two breast cancer cohorts. Endocr Relat Cancer. 2015;22(3): 331-43.

16. Fingar DC, Richardson CJ, Tee AR, Cheatham L, Tsou C, Blenis J. mTOR controls cell cycle progression through its cell growth effectors S6K1 and 4E-BP1/eukaryotic translation initiation factor 4E. Mol. Cell. Biol. 2004;24(1):200-216.

17. Chiang $G G$ and Abraham RT. Phosphorylation of mammalian target of rapamycin (mTOR) at Ser2448 is mediated by p70S6 Kinase. J. Biol. Chem. 2005;280(27):25485-25490.

18. Liu L, Cardelli JA, Martin KA, Blenis J, Huang S. Rapamycin inhibits cell motility by suppression of mTOR-mediated S6K1 and 4E-BP1 pathways. Oncogene. 2006;25(53):7029-7040. 
19. Kim D, Akcakanat A, Singh G, Sharma C, MericBernstam $F$. Regulation and localization of ribosomal protein S6 kinase 1 isoforms. Growth Factors. 2009;27(1):12-21.

20. Rosner M, Hengstschläger M. Nucleocytoplasmic localization of p70 S6K1, but not of its isoforms p 85 and p31, is regulated by TSC2/mTOR. Oncogene. 2011;30(44):4509-4522.

21. Ben-Hur V, Denichenko P, Siegfried Z, Maimon A, Krainer A, Davidson B, Karni R. S6K1 Alternative Splicing Modulates Its Oncogenic Activity and Regulates mTORC1. Cell Reports. 2013;3(1): 103115.

22. Zaiets I, Sivchenko A, Khoruzhenko A, Filonenko V. Generation of HEK-293 stable cell lines with disrupted expression of ribosomal protein S6 kinase (S6K1) isoforms using the CRISPR/Cas9 genome editing system. Biopolym cell. 2017;33(5):356-366.

23. Zaiets I, Sivchenko A, Khoruzhenko A, Savinska L, Filonenko $V$. The p60-S6K1 isoform of ribosomal protein S6 kinase 1 is a product of alternative mRNA translation. Ukr. Biochem. J. 2018;90(4): 25-35.

24. Zaiets I, Holiar V, Sivchenko A, Smialkovska V, Filonenko $V$. p60-S6K1 represents a novel kinase active isoform with the mode of regulation distinct from p70/p85-S6K1 isoforms. Ukr. Biochem. J. 2019;91(4):17-25.

25. Savinska L, Kijamova R, Pogrebnoy P, Ovcharenko G, Gout I, Filonenko V. Comparative characterization of S6 kinase $\alpha$ and $\beta$ isoforms expression in mammalian tissues. Biopolym Cell. 2001;17(5):374-9.

26. Gotsulyak N, Kosach V, Cherednyk O, Tykhonkova I, Khoruzhenko A. Optimization of cell motility evaluation in scratch assay. Biopolym Cell. 2014;30(3): 223-228.

27. Comsa S, Cimpean A, Raica M. The Story of MCF-7 Breast Cancer Cell Line: 40 years of Experience in Research. Anticancer Res. 2015;35(6):3147-54.

28. Berven L, Willard F, Crouch M. Role of the p70(S6K) pathway in regulating the actin cytoskeleton and cell migration. Exp Cell Res. 2004;296(2): 183-95.

29. Chiang GG and Abraham RT. Phosphorylation of mammalian target of rapamycin (mTOR) at Ser-
2448 is mediated by p70S6 Kinase. J. Biol. Chem. 2005;280(27):25485-25490.

30. Liu L, Cardelli JA, Martin KA, Blenis J, Huang S. Rapamycin inhibits cell motility by suppression of mTOR-mediated S6K1 and 4E-BP1 pathways. Oncogene. 2006;25(53):7029-7040.

31. Saxton RA, Sabatini DM. mTOR Signaling in Growth, Metabolism, and Disease. Cell. 2017; 168:960-967.

\section{Зміни експресії ізоформ S6K1 у клітинах лінії МCF-7 мають сильний вплив на рухливість, а також на S6K1 i Akt сигналінг}

В. Р. Косач, Н. Я. Гоцуляк, І. В. Заєць, О. М. Скороход, Л. О. Савінська, А. І. Хоруженко, В. В. Філоненко

Мета. Створити клітинні лінії MCF-7 з вибірковою експресією p85, p70 та p60 ізоформ S6K1: p85-/p70-/ p60 - MCF-7 та p85-/p70-/p60+ MCF-7. Методи. CRISPR/cas9 система редагування генома, вестернблот аналіз, імунофлуоресцентний аналіз, метод «раневої поверхні». Результати. Створено модифіковані клітини лінії МCF-7 з заблокованою експресією р85, p70, p60 чи тільки p85 та p70 ізоформ S6K1. Продемонстровано, що вибіркове інгібування експресії лише р85 та р70 ізоформ S6K1 в клітинах p85-/p70-/ p60 $\mathrm{MCF}-7$ супроводжується перебудовами актинового цитоскелету, появою клітин фібробласто-подібного фенотипу та суттєвим підвищенням міграційної активності клітин. Однак, пригнічення експресії всіх трьох ізоформ в клітинах p85-/p70-/p60- MCF-7 негативно впливало на міграцію клітин и не мало впливу на клітинну морфологію. В той же час зміни в експресії ізоформ S6K1 мали різний вплив на фосфорилювання рибосомного білка S6 та Akt сигналювання. Висновок. Аналіз створених модифікованих клітин лінії МCF-7 дозволив виявити різний вплив експресії ізоформ S6K1 на локомоторну активність клітин та на S6K1 - та Akt-залежне сигналювання. Відповідно до представлених даних, серед досліджуваних ізоформ S6K1 саме p60-S6K1 може бути залученою до регуляції міграції клітин. Модифіковані клітинні лінії MCF-7 надалі можуть бути використані для подальшого дослідження функціональної активності ізоформ S6K1. 
Ключ ов і сл в в: mTOR/S6K1 сигналювання, MCF-7, S6K1, CRISPR/Cas9, рак молочної залози.

Изменения экспрессии изоформ S6K1 в клетках линии МСF-7 имеют сильное влияние на подвижность, а также на S6K1

\section{и Akt сигналинг}

В. Р. Косач, Н. Я. Гоцуляк, И. В. Заєць, А. Н. Скороход, Л. А. Савинская, А. И. Хоруженко, В. В. Филоненко

Цель. Создать клеточные линии MCF-7 с избирательной экспрессией p85, p70 и р60 изоформ S6K1: p85-/ p70-/p60-MCF-7 и p85-/p70-/p60+MCF-7. Методи. CRISPR/cas9 система редактирования генома, вестерн-блот анализ, імунофлуоресцентный анализ, метод «раневой поверхности». Результаты. Создано модифицированные клеточные линии MCF-7 с заблокированной экспрессией p85, p70, p60 или только p85 и р70 изоформ S6K1. Продемонстрировано, что избирательное ингибирование экспрессии р85 и р70 изоформ S6K1 в клетках p85-/p70-/p60 $\mathrm{MCF}-7$ сопровождалось перестройками актинового цитоскелета, по- явленим клеток с фибробласто-подобным фенотипом и существенным повышением миграторной активности клеток. Однако, ингибирование экспрессии всех трех изоформ в клетках p85-/p70-/p60- MCF-7 негативно влияло на миграцию клеток и не влияло на их морфологию. В то же время изменения в экспрессии изоформ S6K1 по-разному влияло на фосфорилирование рибосомного белка S6 и Akt сигналинг. Вывод. Анализ созданных модифицированых линий клеток MCF-7 позволил выявить разное влияние экспрессии изоформ S6K1 на локомоторную активность клеток и на S6K1 - и Akt-зависимый сигналинг. B соответствии с представленнями данными среди исследуемых изоформ S6K1, именно p60-S6K1 может бать вовлечена в регуляцию миграции клеток. Модифицированные клеточные линии MCF-7 в дальнейшем могут быть использованы для исследования функциональной активности изоформ S6K1.

К л юче в ы е с л о в а: $\mathrm{mTOR} / \mathrm{S} 6 \mathrm{~K} 1$ сигналинг, MCF-7, S6K1, CRISPR/Cas9, рак молочной железы.

Received 10.01.2020 